\title{
E-Encyclopedia of Mathematics Based on Android For Class VIII Junior High School
}

\author{
Ririn Dwi Agustin \\ Pendidikan Matematika, FPIEK, IKIP Budi Utomo Malang \\ e-mail: ririndwiagustin@budiutomomalang.ac.id
}

\begin{abstract}
Mathematics is a broad science in life. Therefore learning media innovation must be done. The purpose of this research is to create applications that can expand knowledge and skills by attracting and flexible with android based systems for grade VIII students of junior high school. Android is an operating system that is Open Source which gives freedom for developers to develop an application, with the advantages of the Android operating system, will help Android-based users to be able to joyfull a variety of applications, one of the applications is e-encyclopedia. The stages of the research carried out refer to the ADDIE development model including Analysis, Design, Development, Implementation, and Evaluation. The stages of the research that have been carried out are the Stages of research that have been carried out are goal analysis (goal analysis, analysis of learning tools and materials, analysis of ability levels and characteristics of target users), design (application design to be presented, preparation of materials, preparation of material delivery flow in the form of flowcharts, making flowcart, and approve materials needed in encyclopedia development), development (application development), implementation (computer expert approval, material experts, and field discussions and conducting limited trials), and evaluations (evaluation of applications developed, carried out for forty before).. The subjects involved grade VIII students were 10 female students and 12 male students as respondents. Feasibility test results were obtained $95 \%$ for media experts, $90 \%$ for material experts, $80 \%$ for field practitioners, and $83 \%$ for target users.
\end{abstract}

Keywords : E-encyclopedia, Media, Android

\section{INTRODUCTION}

The development of time, media and technology have an important influence on education. This has become a daily consumption need. Some are even addicted to technology in the form of smartphones, laptops, computers, and the internet. This has influenced the learning process to date. Conventional learning media in the current milleneal era has become increasingly difficult to find. Learning media is a tool that can convey or deliver learning messages (Arsyad, 2015: 3). The use of interesting learning media will increase students' motivation and interest in learning which will ultimately make students successfully understand the material provided (Setyadi and Qohar, 2017: 1). Learning media that can be used with technological advances in the form of learning applications on gadgets. In learning media able to train knowledge, skills and accuracy in the learning system in a more interesting way.

One effort to utilize Android is to develop a mobile apps, which will play a role in making Android a learning media for mathematics. So far, there are already android mobile apps that are used as learning media. One developer who has developed Androbook Chemistry (2016) as a chemical learning media is Najid Azma. Androbook Chemistry is made for students with disabilities speaking as an independent learning 
media. In this study an android application developed is the Mathematical Encyclopedia which contains learning content consisting of material in semester 1 and 2 of class VIII for SMP / MTs. The filled material contains the define of the material discussed in each chapter and there are also sample questions and question exercises.

Android application is one of the approaches in the learning process. Application development on android can be used as a medium of learning mathematics so that it is easy to achieve learning goals in cognitive, affective and psychomotor aspects. In understanding the concepts in learning mathematics which is a cognitive ability. Understanding the concept is the ability to explain, explain, interpret, or capture a meaning of the object being studied so that it is not just remembering facts (Sanjaya, 2010).

\section{RESEARCH METHOD}

The Stages of research conducted on the ADDIE development model developed by (Dick, 1978), while the development therein is called Analysis, Design, Development, Implementation, and Evaluation. Stages of research that have been carried out are goal analysis (goal analysis, analysis of learning tools and materials, analysis of ability levels and characteristics of target users), design (application design to be presented, preparation of materials, preparation of material delivery flow in the form of flowcharts, making flowcart, and approve materials needed in encyclopedia development), development (application development), implementation (computer expert approval, material experts, and field discussions and conducting limited trials), and evaluations (evaluation of applications developed, carried out for forty before).

The formula used is

$$
P=\frac{\sum X}{N} \times 100 \%, N A=\frac{\sum P}{n}
$$

adopted from (Arikunto, 2010)

Information :

$P=$ percentage score

$N A=$ final score

$\Sigma \mathrm{X}=$ total score

$N=$ maximal score

$n=$ many questions

To determine the level of validity of the developed e-encyclopedia, criteria for qualification assessment based on (Arikunto, 2010) will be used as shown in table 1

\begin{tabular}{llll}
\hline Percentace $(\%)$ & Validity Level & Category & \\
\hline $\mathbf{7 6 - 1 0 0}$ & Valid & $\begin{array}{l}\text { Feasible/no } \\
\text { needed }\end{array}$ & revision \\
& Quite & feasible/partial \\
$\mathbf{5 1 - 7 5}$ & Quite Valid & revision & Less feasible/partial revion \\
& Less Valid & Infeasible/total revison \\
\hline $\mathbf{2 5 - 5 0}$ & Invalid & & \\
\hline $\mathbf{2 6}$ & &
\end{tabular}




\section{RESULTS AND DISCUSSION}

The results in this study are: the mathematical e-encyclopedia has been developed and the results of the mathematical e-encyclopedia of this research have been validated by experts to determine its validity and eligibility. The assessment results show that this mathematical e-encyclopedia has fulfilled a valid categories based on expert validation assessment, namely a computer expert and also a material expert. Whereas based on limited test tests from teachers and 21 students in the mathematical e-encyclopedia that was developed to obtain results with practical and effective criteria. Based on the criteria of validity, practicality and effectiveness of the developed e-encyclopedia application is fulfilled, and the final product is obtained in the form of a mathematical e-encyclopedia.

The e-encyclopedia application was developed in the form of an Android APK application that supports Android. So this applications, was developed flexibly. This learning media includes mobile learning based learning. This is in accordance with the definition of cellular learning stated by (O'Malley, 2013), namely learning so that students (students) do not remain silent in one place or learning activities that occur when students use mobile technology devices.

The trial results show that many 8th grade students are interested in this application because it is very easy to use. Students already use Android so that students feel worthy as a medium for learning in school, the road, home and anywhere.

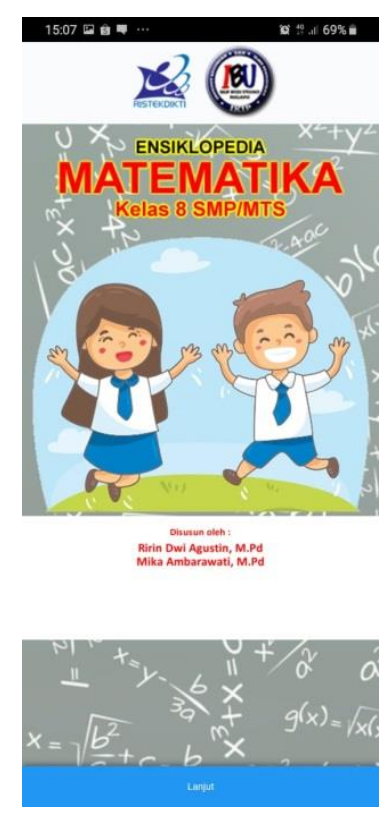

Figure 1. Front Page E-Encyclopedia 


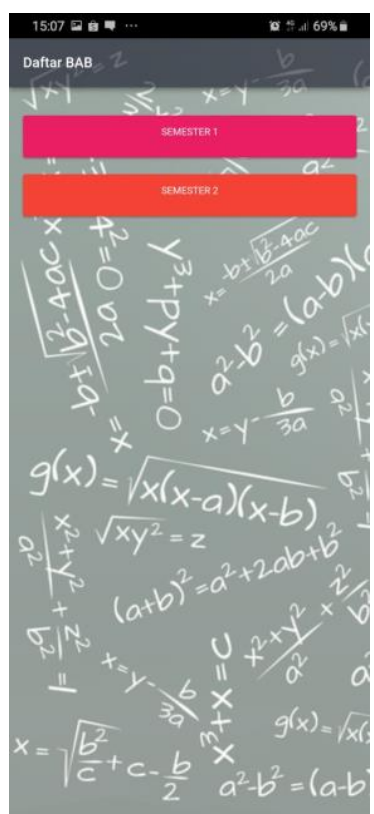

Figure 2. semester 1 and 2 materials for class VIII Junior High School in the Mathematics e-encyclopedia

In this application there are several main menus, encyclopedia cover, choice of material in Semester 1 and semester 2, material for each semester in accordance with student books. The "Font Page" menu contains the title of the encyclopedia as well as the author. On the "semester options" menu contains the semester options to be selected according to student needs. In the "Material" menu, users can access all the desired material that contains several terms related to the material presented. This is in accordance with the opinion of (Terrell, 2011) about several criteria that make mobile learning effective.

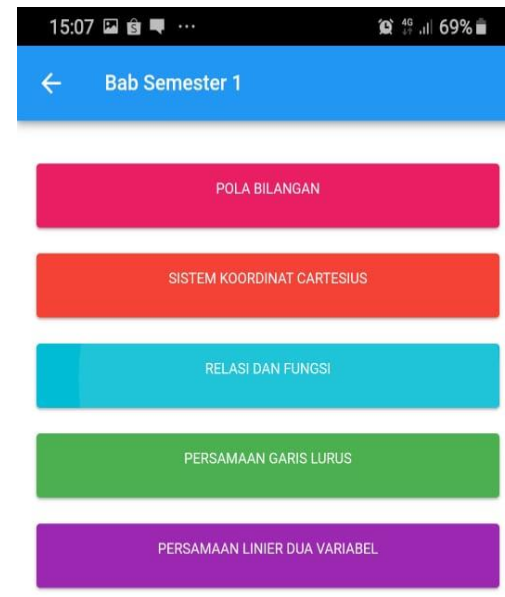

Figure 3. Option all material available in semester 1 in the Mathematics e-encyclopedia 
Mathematics Education Journals Vol. 4 No. 1 February 2020
ISSN : 2579-5724

ISSN : 2579-5260 (Online)

http://ejournal.umm.ac.id/index.php/MEJ

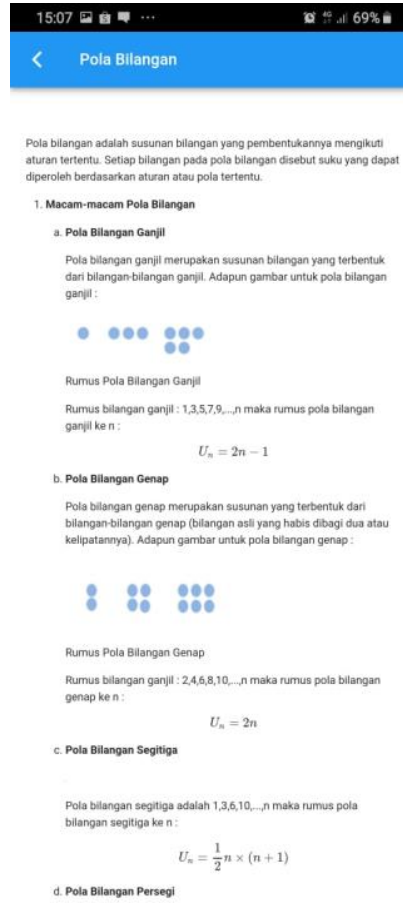

Figure 4 sample material sub-chapter in semester 1

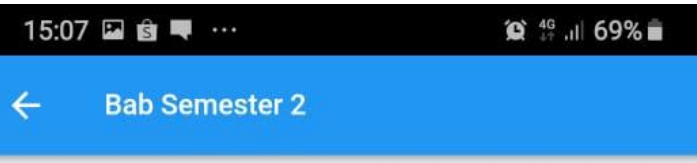

TEOREMA PHYTAGORAS

LINGKARAN

BANGUN RUANG SISI DATAR

STATISTIKA

PELUANG

Figure 5. Option material chapter in semester 2 in the Mathematics e-encyclopedia 


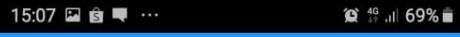 \\ $<$ Teorema Phytagoras
}

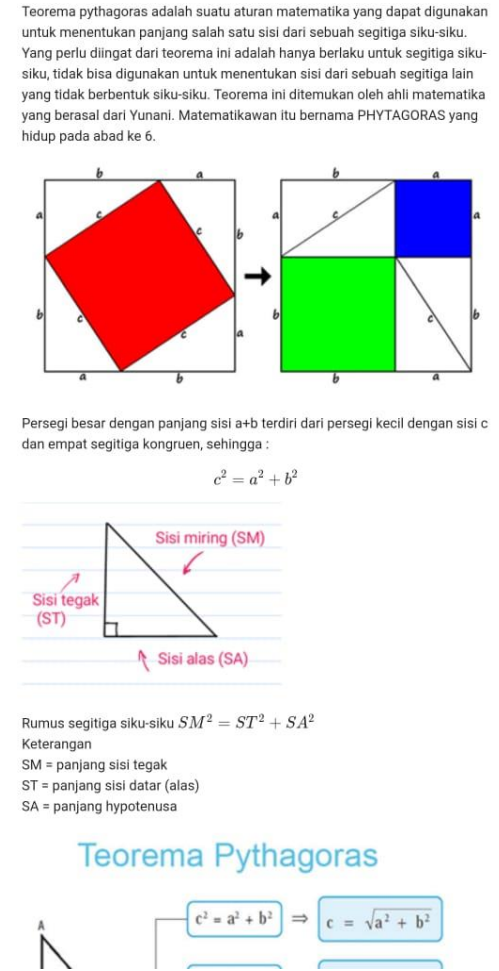

Figure 6 sample material sub-chapter in semester 2

Based on the results of a trial of 21 Sri Wedari Junior High School students that have been conducted, the results obtained are a mathematical e-encyclopedia application that was developed to get a grade worthy of use. This is in accordance with the criteria of quality learning media based on criteria proposed by (Elissavet, Georgiadou and Economides, 2000).

\section{Comments and Suggestions}

\author{
Computer Expert \\ add some more varied features such as animation \\ Material Expert \\ add more materials
}

Feasibility test results were obtained $95 \%$ for media or computer experts, $90 \%$ for material experts, $80 \%$ for field trials, and $83 \%$ for target users. Therefore, the mathematical e-encyclopedia application developed is suitable for use as a learning media. Learning media developed have advantages, which can be operated on Android and Windows-based devices; presenting material for junior high schools with flexible and easy to understand; presents a help definition to help students understand the material in each subject. In addition to the advantages mentioned earlier, the learning media developed also have weaknesses. Weaknesses of learning media developed include that learning media cannot be operated on mobile devices with operating systems other than Android.

Table 3 Comments and Suggestions by Practitioner Expert

Expert Comments and Suggestions

Practitioner it is better to give examples of questions and practice questions on each subject 
Table 4 Comments and Suggestions by Users (students)

\begin{tabular}{ccl}
\hline No & Subject & Comments and Suggestions \\
\hline 1 & A & $\begin{array}{l}\text { this practical e-encyclopedia application so that it can study } \\
\text { anywhere }\end{array}$ \\
\hline 2 & B & can the e-encyclopedia application be added to the game? \\
\hline 3 & C & learning mathematics becomes interesting \\
\hline 4 & D & for more applications like this that have many games \\
\hline
\end{tabular}

Applications developed in this research can only be run on Android-based mobile devices and computers. It is hoped to develop similar applications that can run on devices with different operating systems and on different materials. With the development of learning applications such as this technology, it is expected to increase the benefits of smartphones in the field of education and add student interest. In addition, the existence of applications like this can provide a more interesting and exciting learning experience for students.

\section{CONCLUSION}

The product developed is a mathematical e-encyclopedia in the form of an Android application. This application can also be operated on a computer or laptop with the Windows operating system. To install this application is very easy even can be sent via whatapps or email. This application presents two sub-topic material in each semester. In semester 1 there is material: Number Patterns, Cartesian Coordinate Systems, Relationships and Functions, Straight Line Equations, Linear Equations of Two Variables. While in semester 2 there are material: Pythagorean Theorem, Circles, Flat Side Building, Statistics, and Opportunities.

In this application there are several main menus, encyclopedia cover, choice of material in Semester 1 and semester 2, material for each semester in accordance with student books. The "Font Page" menu contains the title of the encyclopedia as well as the author. On the "semester options" menu contains the semester options to be selected according to student needs. In the "Material" menu, users can access all the desired material that contains several terms related to the material presented. This is in accordance with the opinion of (Terrell, 2011) about several criteria that make mobile learning effective..

Feasibility test results were obtained $95 \%$ for media or computer experts, $90 \%$ for material experts, $80 \%$ for field trials, and $83 \%$ for target users. Therefore, the mathematical e-encyclopedia application developed is suitable for use as a learning media. Learning media developed have advantages, which can be operated on Android and Windows-based devices; presenting material for junior high schools with flexible and easy to understand; presents a help definition to help students understand the material in each subject. In addition to the advantages mentioned earlier, the learning media developed also have weaknesses. Weaknesses of learning media developed include that learning media cannot be operated on mobile devices with operating systems other than Android. 


\section{REFERENCES}

Arikunto, S. (2010). Prosedur Penelitian Suatu Pendekatan Praktik. Yogyakarta: Rineka Cipta.

Baktha, K. (2017). Mobile Application Development: All the Steps and Guidelines for Successful Creation of Mobile App : Case Study. International Journal of Computer Science and Mobile Computing, 6(9), 15-20.

Darling Hammond, L. (2019). Implications for educational practice of the science of learning and development. Applied Developmental Science. https://doi.org/https://www.tandfonline.com/doi/full/10.1080/10888691.2018.1537 791

Dick, W. dan L. C. (1978). The Systematic Design of Instruction. USA: Scott, Foresman and Company.

Elissavet, Georgiadou and Economides, A. A. (2000). Evaluation Factors of Educational Software. In Proceedings International Workshop on Advanced Learning Technologies (IWALT) (pp. 113-120). California: IEEE. Retrieved from http://conta.uom.gr/conta/publications/PDF/Evaluation Factors of Educational Software.pdf

Georgiev,Tsvetozar, D. (2004). M-Learning - a New Stage of E-Learning. In International Conference on Computer Systems and Technologies. Retrieved from http://ecet.ecs.ru.acad.bg/cst04/docs/siv/428.pdf,

Ghavifekr, S., Afshari, M., \& A. S. (2012). Management strategies for E-Learning system as the core component of systemic change: A qualitative analysis. Life Science Journal, 9(3), 2190-2196.

Grabe, M. (2007). Integrating Technology for Meaningful Learning. (James R. Layton, Ed.) (Vol. 2). USA: Southwest Missouri State University, Springfield, MO, USA.

Hidayanti, N. I. Perancangan Dan Pembuatan Ensiklopedia Matematika Digital Dalam Komunitas Dan Pembelajaran Matematika (2014).

Jethro, O. O., Grace, A. M., \& Thomas, A. K. (2012). E-Learning and Its Effects on Teaching and Learning in a Global Age, 2(1), 203-210. Retrieved from http:/hrmars.com/admin/pics/484.pdf

O’Malley, C. (2013). Guidelines For Learning/Teaching/Tutoring in a Mobile Environtment. Retrieved from http://www.mobilearn.org/download/results/guidelines.pdf

Rokhman F, M. S. A. (2014). Character Education for Golden Generation 2045 (National Character Building for Indonesian Golden Years)No Title. Procedia - Social and Behavioral Sciences, 141, 1161-1165. https://doi.org/https://doi.org/10.1016/j. sbspro.2014.05.197

Terrell, S. S. (2011). Effective Mobile Learning, 50 + Quick Tips \& Resources. Retrieved from http://www.scribd.com/doc/67369598/Effective-Mobile-Learning-50-TipsResources-Ebook 